Original Research Article

\title{
Comparison of Levetiracetam and sodium Valproate in the prevention of migraine: a randomized clinical trial study
}

\author{
Vahid Abbasi ${ }^{1}$, Abolfazl Atalu ${ }^{1 *}$, Perham Seddighnia ${ }^{2}$
}

${ }^{1}$ Department of Neurology, ${ }^{2}$ Faculty of Medicine, Ardabil University of Medical Sciences, Ardabil, Iran

Received: 13 June 2018 Accepted: 09 July 2018

*Correspondence to:

Dr. Abolfazl Atalu, Email: a.atalou@arums.ac.ir

Copyright: (C) the author(s), publisher and licensee Medip Academy. This is an openaccess article distributed under the terms of the Creative Commons Attribution NonCommercial License, which permits unrestricted noncommercial use, distribution, and reproduction in any medium, provided the original work is properly cited.

\begin{abstract}
Background: Sodium valproate is an anti-seizure drug used for prophylactic use of migraine headaches. Despite the efficacy of this drug due to complications that cause some patients to not tolerate the drug. The purpose of this study was to Comparison of levotiracetam and Sodium valproate in migraine prophylaxis.

Methods: This is a clinical trials study. 100 migraineurs who referred to the Alavi neurology clinic and indicated the onset of prophylaxis of migraine were studied in two groups of 50, one of which was a group of levetiracetam and another group of sodium valproate Received. Patients received daily $500 \mathrm{mg}$ of drug for 3 months and the effect of the drug on the number of attacks, severity of attacks, and MIDAS score was measured. Collected data analyzed by statistical methods in SPSS version 19. $\mathrm{P}<0.05$ was considered as significant.

Results: In both cases, significant improvement was observed in the number of attacks, severity and MIDAS score. In all of the criteria, levetiracetam and sodium valproate were almost identical, except for reducing the number of headache attacks that had a significantly in levothyramine group less than sodium valporoste group $(\mathrm{P}=0.0001)$.

Conclusions: This study showed that levothyramineacetamin can be used as a good alternative in those who do not tolerate sodium valproate.
\end{abstract}

Keywords: Levetiracetam, Migraine, Sodium valproate

\section{INTRODUCTION}

Headache is the most common cause of referral to the doctor and the incidence probability of a headache during life for women and men were $95 \%$ and $90 \%$, respectively. Among the causes of headache, migraine is one of the most common headache that affects $18.2 \%$ of women and $6.5 \%$ of men aged 12-80 years. ${ }^{1}$ Migraines usually start in the second decade of life and $90 \%$ of patients experience the first migraine attack until age $40 .^{2}$ Every migraine attack takes about 4-7 hours and usually its severity is so severe that it interferes with people's daily activities, occupational and individual performance. ${ }^{1}$

Migraines are a common disabling disorder. People with migraine often suffer from severe headaches. These headaches are usually associated with autonom symptoms. Frequency, duration and severity of migraine attacks vary from person to person and most of migraine patients experience courses of temporary disability in migraine attacks. These attacks affect individual activity and quality of life. Therefore, attention to the treatment and prevention of migraine is very important. Migraine may be a progressive disorder that in the absence of treatment, turns from episodic to chronic state while aggressive treatment may prevent this progress. ${ }^{3}$ Treatment of migraines is divided into symptomatic and preventative types and patients with more than 3-4 attacks per month or severity causing a patient's disability require prophylaxis. ${ }^{4,5}$ Preventive treatments included medication, dietary changes, physical therapy and prevention of psychological stress and preventing exacerbating factors. ${ }^{6}$ The most 
effective preventive drugs for migraine attacks are : Beta receptor antagonists, anticonvulsants, antidepressants and calcium channel blockers. ${ }^{7}$ Sodium Valproate is an antiseizure drug. This drug was approved in the year 2000 by FDA for the prevention of migraines. Side effects of sodium valproate included tremor, obesity, hair loss and fetal complications during pregnancy. ${ }^{8}$ Levetiracetam is another anticonvulsant drug approved by the FDA to treat seizures and its mechanism not known yet. ${ }^{9}$ But in several studies, its effect on chronic headaches has been reported. Side effects of Levetiracetam included insomnia, irritability, dizziness and blurred vision. This drug had renal excretion and a half life of 7 to 8 hours. ${ }^{10}$ The aim of this study was to compare the effect of Levetiracetam (L) and sodium Valproate (SV) in the prevention of migraine.

\section{METHODS}

\section{Study design and patients}

We conducted a prospective, randomized clinical trial study. A total of 86 patients were randomized to receive levetiracetam $500 \mathrm{mg} / \mathrm{d}(\mathrm{n}=42)$ and valproate $500 \mathrm{mg} / \mathrm{d}$ $(n=44)$. The patients were evaluated for treatment efficacy after 3 months. Efficacy was assessed as a more than $50 \%$ decrease in headache frequency.

\section{Inclusion criteria}

Patients with a history of migraine, the number of migraine attacks from 4 to 15 times in a month, failure of prophylactic treatment with one or more migraine prevention drugs and age 16 to 65 years old were included in the study.

\section{Exclusion criteria}

Patients with a history of sodium valproate and levetiracetam use, breast feeding duration, had underlying illnesses such as liver and kidney failure, drug and alcohol use, smoking, the use of sedative medications and pregnant women were excluded from the study.

\section{Data collection}

Demographics data were completed at the start of the study and completed MIDAS form. MIDAS questions indicate the days of absence at work, days of reduced work efficiency by more than $50 \%$, days of inability to do homework and days of non attendance at social and recreational activities and family meetings due to migraine in the past 3 months. The score and rank of MIDAS, frequency and severity of attacks determined by the patient himself. During the study, the selected individuals could be divested from the study. patients were visited 3 times in 3 months and in each visit questions related to the MIDAS factors monthly and the rate of use of acute drugs for acute headache attacks during the past month and the side effects of drugs recorded in a checklist. The medications were prescribed to the patient to contact the doctor if they have a contamination. Patients with intolerance to the drug were divested from the study at each stage. Patients were visited monthly and the efficacy of treatment based on the frequency of migraine attacks per month, the change in the MIDAS score and the severity of headache were recorded by the patient's own scoring scale with a headache intensity of 0 to 10 and also the reduction in the use of acute treatment for the attacks was measured. All patients advise on avoiding lack of sleep and sleeping and avoiding factors such as (high consumption of caffeine, long term hunger, noisy environments, alcohol and smoking) which worsen their migraine headache.

This study was registered with code of ethics IR.ARUMS.REC.1396.133 and IRCT registration number IRCT20171011036717N1. All patients completed the consent form.

\section{Statistical analysis}

Collected data were analyzed by SPSS version 22 using descriptive and analytical statistical methods. The level of significance was less than 0.05 .

\section{RESULTS}

There was no significant difference between two groups in terms of age, sex, diet, education level, history of headache, headache frequency, headache acute drug use and MIDAS (Table 1). Of the levetiracetam group, 9 $(21 \%)$ were male and $33(79 \%)$ were female of sodium valproate group, 8 (18\%) were male and $36(82 \%)$ were female. The average age of group Sodium valproate was $35.14 \pm 3.7$ and levetiracetam group was $36.33 \pm 6.6$ and the mean age of the all patients was $35.91 \pm 6.9$. This difference wasn't significant. The duration of migraine was $9.95 \pm 5.93$ in group Sodium valproate and $10.95 \pm 5.43$ years in group levetiracetam and $10.47 \pm 6.63$ years in all group. This difference was not significant (Table 1).

The headache frequency in group Sodium valproate was $4.6 \pm 1.75$ and in group levetiracetam was $2.6 \pm 1.43$ which was not statistically significant in the baseline. After 3 months the headache frequency was $3.9 \pm 1.18$ and $2.29 \pm 0.88$ in groups Sodium valproate and levetiracetam, respectively which was statistically significant difference $(\mathrm{P}=0.0001)$ and indicates a better levetiracetam effect.

The duration of migraine attack was $16.63 \pm 6.8$ in group Sodium valproate and $14.21 \pm 4.5$ in group levetiracetam respectively that it was not statistically significant. After 3 months of treatment the duration of migraine attack was $11.4 \pm 6.9$ and $10.5 \pm 2.5$ in the Sodium valproate and levetiracetam groups respectively and the difference was statistically significant $(\mathrm{P}=0.0001)$.

The severity of headache in group Sodium valproate was $7.67 \pm 1.64$ and in the group levetiracetam was $7.64 \pm 1.67$ which wasn't statistically significant. After 3 months of treatment, the duration of headache severity in the Sodium 
valproate and levetiracetam groups was $4 / 62 \pm 2 / 6$ and $4 / 33 \pm 2 / 24$ in groups Sodium valproate and levetiracetam respectively and the difference was statistically significant $(\mathrm{P}=0.004)$.

The mean of MIDAS score in group Sodium valproate was $2.67 \pm 1.19$ and in group levetiracetam was $2.64 \pm 1.19$ and wasn't statistically significant difference. After 3 months of treatment, the average MIDAS score in the Sodium valproate and levetiracetam groups was $1.27 \pm 1.11$ and $9.15 \pm 0.81$ respectively which was statistically significant difference $(\mathrm{P}$ value $=0.001)$.

Table 1: Comparison of frequency, duration, intensity of headache and MIDAS score in two groups before prescribing the drug (at baseline).

\begin{tabular}{|c|c|c|c|c|}
\hline variables & group & mean & SD & $\begin{array}{l}\text { P } \\
\text { value }\end{array}$ \\
\hline \multirow{2}{*}{$\begin{array}{l}\text { Headache } \\
\text { frequency }\end{array}$} & $\begin{array}{l}\text { Sodium } \\
\text { valproate }\end{array}$ & 6.4 & 1.75 & \multirow[t]{2}{*}{0.27} \\
\hline & levetiracetam & 6.2 & 1.43 & \\
\hline \multirow{2}{*}{$\begin{array}{l}\text { Duration of } \\
\text { headache }\end{array}$} & $\begin{array}{l}\text { Sodium } \\
\text { valproate }\end{array}$ & 16.63 & 6.8 & \multirow[t]{2}{*}{0.36} \\
\hline & levetiracetam & 14.21 & 5.4 & \\
\hline \multirow{2}{*}{$\begin{array}{l}\text { Headache } \\
\text { severity }\end{array}$} & $\begin{array}{l}\text { Sodium } \\
\text { valproate }\end{array}$ & 7.67 & 1.64 & \multirow[t]{2}{*}{0.94} \\
\hline & levetiracetam & 7.64 & 1.67 & \\
\hline \multirow{2}{*}{$\begin{array}{l}\text { MIDAS } \\
\text { score }\end{array}$} & $\begin{array}{l}\text { Sodium } \\
\text { valproate }\end{array}$ & 2.67 & 1.09 & \multirow[t]{2}{*}{0.91} \\
\hline & levetiracetam & 2.64 & 1.08 & \\
\hline \multirow[t]{2}{*}{$\begin{array}{l}\text { The duration } \\
\text { of migraine }\end{array}$} & $\begin{array}{l}\text { Sodium } \\
\text { valproate }\end{array}$ & 9.95 & 5.4 & \multirow[t]{2}{*}{0.7} \\
\hline & levetiracetam & 10.95 & 5.6 & \\
\hline \multirow[t]{2}{*}{ Age } & $\begin{array}{l}\text { Sodium } \\
\text { valproate }\end{array}$ & 35.14 & 7.3 & \multirow[t]{2}{*}{0.5} \\
\hline & levetiracetam & 36.32 & 6.6 & \\
\hline
\end{tabular}

Table 2: Comparison of frequency, duration and severity of headache and MIDAS score after the administration of the drug.

\begin{tabular}{|l|lll|l|}
\hline Variables & Group & Mean & SD & $\begin{array}{l}\text { P } \\
\text { value }\end{array}$ \\
\hline $\begin{array}{l}\text { Headache } \\
\text { frequency }\end{array}$ & $\begin{array}{l}\text { Sodium } \\
\text { valproate }\end{array}$ & 3.9 & 1.18 & \multirow{2}{*}{0.001} \\
\cline { 2 - 4 } & Levetiracetam & 2.29 & 0.88 & \\
\hline $\begin{array}{l}\text { Duration } \\
\text { of } \\
\text { headache }\end{array}$ & $\begin{array}{l}\text { Sodium } \\
\text { valproate }\end{array}$ & 11.4 & 6.09 & \multirow{2}{*}{0.001} \\
\cline { 2 - 4 } $\begin{array}{l}\text { Levetiracetam } \\
\text { Headache } \\
\text { severity }\end{array}$ & $\begin{array}{l}\text { Sodium } \\
\text { valproate }\end{array}$ & 10 & 5.2 & \\
\cline { 2 - 4 } & Levetiracetam & 4.33 & 2.24 & \multirow{2}{*}{0.001} \\
\hline \multirow{2}{*}{$\begin{array}{l}\text { MIDAS } \\
\text { score }\end{array}$} & $\begin{array}{l}\text { Sodium } \\
\text { valproate }\end{array}$ & 1.27 & 0.45 & \multirow{2}{*}{0.001} \\
\cline { 2 - 4 } & Levetiracetam & 1.15 & 0.36 & \\
\hline
\end{tabular}

\section{DISCUSSION}

Although the efficacy of sodium valproate in preventing migraine has been confirmed in valid clinical studies and this drug is one of the approved drugs in the prevention of migraine. But long term use of this medication due to its side effects (depression, muscle weakness, tremor, ataxia, headache, insomnia, drowsiness, drowsiness, blurred vision, nausea, vomiting, indigestion, diarrhea, abdominal cramps, constipation, increased Appetite, anorexia, hepatitis, weight gain, alopecia, multiple form erythema, flu like syndrome, itching, rash, Stevens Johnson syndrome) can be limited in future. ${ }^{11}$

This study is in line with previous studies that reported the efficacy of levetiracetam in preventing migraines. Virgilio Gallai et al, in a study reported a reduction of $50 \%$ in the number of headache attacks after receiving levetiracetam and showed that the number of migraine attacks was significantly reduced, which was in line with the result of our study which showed high efficacy of levetiracetam. ${ }^{12}$ In this study, the dosage of levetiracetam was $500 \mathrm{mg}$ per day that no adverse drug effect was observed in any of the patients it may be due to low dose medication. Sdeghian in a study in the Tehran showed that the levetiracetam had a $50 \%$ reduction in the number of migraine attacks after receiving levetiracetam and has a comparable effect with other antiepileptic drugs such as sodium valproate which was in line in this study results. ${ }^{13}$

M. Homam and et al, in a study in Mashhad showed that the side effects of levetiracetam was lower than sodium valproate. ${ }^{14}$ In the present study, both drugs had significant effects in reducing attacks and severity of migraine attacks of course in this study the effect of levetiracetam on the reduction of headache frequency was greater than that of sodium valproate. Stewart and et al reported a $50 \%$ decrease in the number of headache attacks after levetiracetam receiving and levetiracetam did not have any side effects and levetiracetam was considered as a new preventive treatment for the treatment of migraine without aura which was in line with the results of this study. ${ }^{15}$ Verma and et al reported a reduction $50 \%$ in the migraine attacks after levetiracetam treatment which was in line with our study results. ${ }^{16}$

\section{CONCLUSION}

Results showed that both of levetiracetam and sodium valproate were effective in reducing the frequency, severity and duration of headache and MIDAS score. Of course, the reduction of headache frequency in levetiracetam group was significantly higher than sodium valproate group. It seems that the levetiracetam in preventing migraine headaches was better than sodium valproate and also due to less complications of levetiracetam it can be used as an alternative medicine in future. 
Conflict of interest: None declared

Ethical approval: The study was approved by the Institutional Ethics Committee (IR.ARUMS.REC.1396.133)

\section{REFERENCES}

1. Boes CJ, Capobianco DJ, Cutrer FM, Dodick DW, Eross EJ, Swanson JW, et al. Neurology in clinical practice. $5^{\text {th }}$ Ed Butterworth, Heinemann; 2008:20262042.

2. Mohammadianinejad SE, Babaei M, Nazari P. The Effects of Exposure to Low Frequency Electromagnetic Fields in the Treatment of Migraine Headache: A Cohort Study. Electron Physician. 2016 Dec 25;8(12):3445-9.

3. Colas R, Munoz P, Temprano R, Gomez C, Pascual J. Chronic daily headache with analgesic overuse Epidemiology and impact on quality of life. Neurology. 2004 Apr 27;62(8):1338-42.

4. Friedman DI, De Ver Dye T. Migraine and the environment. Headache: The J Head and Face Pain. 2009 Jun 1;49(6):941-52.

5. Pappagallo M. Newer antiepileptic drugs: possible uses in the treatment of neuropathic pain and migraine. Clinical therapeutics. 2003 Oct 1;25(10):2506-38.

6. Linde K, Rossnagel K. Propranolol for migraine prophylaxis. Cochrane Database of systematic Review 2009;(2):CD003225.

7. Brandes JL, Saper JR, Diamond M, Couch JR, Lewis DW, Schmitt J, et al MIGR-002 Study Group. Topiramate for migraine prevention: a randomized controlled trial. JAMA. 2004 Feb 25;291(8):965-73.

8. Bartolini M, Giamberardino MA, Lisotto C, Martelletti P, Moscato D. A double-blind, randomized, multicenter, Italian study of frovatriptan versus almotriptan for the acute treatment of migraine. The J Heada and Pain. 2011 Jun 1;12(3):361-8.

9. Landmark CJ. Antiepileptic drugs in non-epilepsy disorders Relations Between mechanisms of action and clinical efficacy. CNS Drugs. 2008,22(1):27-47.

10. Eiland LS, Jenkins LS, Durham SH. Pediatric migraine: Pharmacologic agents for prophyloxis. Ann Pharmaco ther. 2007,41:118-90.

11. Zwab A, Canmady J. Safe use of Sodium valproate. Neurology. 2014Aug4;37(8):124-6.

12. Gallai V, Alberti A, Rossi C, Coppola F, Gallai B, et al. An open-label pilot study on the efficacy and tolerability of levetiracetam in the prophylaxis of migraine. J Headache Pain. 2003;4:92-6.

13. Sadeghian H, Motiei-Langroudi R. Comparison of Levetiracetam and sodium Valproate in migraine prophylaxis: A randomized placebo-controlled study. Ann Indian Acad Neurol. 2015;18(1):45-8.

14. Homam M, Farajpour A, Khadem S, Mostafavian Z. The Experiential Comparison of Levetiracetam Efficacy in Migraine Headache with Sodium Valproate. CJNS. 2016;2(5):42-9.

15. Stewart WF, Wood C, Reed ML, Roy J, Lipton RB. Cumulative lifetime migraine incidence in women and men. Cephalalgia. 2008 Nov 1;28(11):1170-78.

16. Verma A, Srivastava D, Kumar A, Singh V. Levetiracetam in migraine prophylaxis: a randomized placebo-controlled study in a rural medical institute in Northern India. Clinical neuro Pharmacol. 2013 Nov 1;36(6):193-7.

Cite this article as: Abbasi V, Atalu A, Seddighnia P. Comparison of Levetiracetam and sodium Valproate in the prevention of migraine: a randomized clinical trial study. Int J Basic Clin Pharmacol 2018;7:1460-3. 